Article

\title{
Information Quality in Latin American Digital Native Media: Analysis Based on Structured Dimensions and Indicators
}

\author{
Claudia Rodríguez-Hidalgo ${ }^{1}$, Diana Rivera-Rogel ${ }^{1}$ and Luis M. Romero-Rodríguez ${ }^{2,3, *}$ \\ ${ }^{1}$ Department of Communication Sciences, Universidad Técnica Particular de Loja, 28005 Loja, Ecuador; \\ E-Mails: cvrodriguezx@utpl.edu.ec (C.R.-H.), derivera@utpl.edu.ec (D.R.-R.) \\ 2 Department of Communication Sciences and Sociology, Rey Juan Carlos University, 28943 Madrid, Spain; \\ E-Mail: luis.romero@urjc.es \\ ${ }^{3}$ ESAI Business School, Espiritu Santo University, 092301 Guayaquil, Ecuador \\ * Corresponding author
}

Submitted: 23 November 2019 | Accepted: 5 February 2020 | Published: 16 April 2020

\begin{abstract}
The current communicative ecosystem has profoundly transformed journalistic work and the media, generating with great eagerness the emergence of digital native media that do not follow the logic of their conventional peers. Although the advent of these media is not entirely negative, as they create multiple voices that contribute to pluralism, their quality has undoubtedly been questioned on several academic fronts. This work analyzes the most important Latin American digital native media by number of accesses (traffic), using a taxonomy of evaluation of dimensions of the informative quality, in which aspects such as informative sources, uses of international news agencies, correction of contents and factuality levels, ideological plurality in their opinion contents, among others, are taken into consideration. Of the emerging results, the 'use of statistical indicators' was the least rated (32.5\%), mainly due to a lack of data journalism in the media studied. It is also worth noting that the indicator 'comments and monitoring' obtained the second-lowest rating, indicating an absence of conversation between the media and its audience through the comments section of each content.
\end{abstract}

\section{Keywords}

digital media; fake news; information quality; journalism; Latin America

Issue

This article is part of the issue "Digital Native News Media: Trends and Challenges" edited by Ramón Salaverría (University of Navarra, Spain).

(C) 2020 by the authors; licensee Cogitatio (Lisbon, Portugal). This article is licensed under a Creative Commons Attribution 4.0 International License (CC BY).

\section{Introduction}

With the rise and popularization of Internet and social networks, conventional media opened their digital channels-webs, podcasts, streaming, fan pagesnot only because the informative consumption began to migrate its platforms, but also because new digital native media that escaped from the informative logics prevailing in past centuries were born (RomeroRodríguez, De-Casas-Moreno, \& Torres-Toukoumidis, 2016), especially regarding editorial verification processes (Salaverría, 2005), information review structures, financing methods, and even the training and experience of new content creators who did not necessarily come from journalism (García-Serrano, Romero-Rodríguez, \& Hernando Gómez, 2019; Romero-Rodríguez \& Aguaded, 2018). This model that brings with it new information vices such as fake news (see Albright, 2017; Lazer et al., 2018; Vosoughi, Roy, \& Aral, 2018), clickbait (Molyneux \& Coddington, 2019), pseudo-journalistic infoxication, and others, leads to a loss of confidence before their audiences (Novak, 2018; Samuel-Arzan \& Hayat, 2019).

Latin America has not been oblivious to these changes and mediamorphosis. From the Caribbean to Patagonia, the 20 Latin American countries have witnessed the birth of digital native media projects in the 
last two decades, which on many occasions achieve high levels of consolidation (Salaverría, Rivera-Rogel, \& González-Córdova, 2019; Salaverría, Sábada, Breiner, \& Warner, 2018), despite the fact that in many countries of the region there are still significant inequalities of access to information due to digital gaps of economic, age, and geographical reasons (Lotero-Echeverri, Romero-Rodríguez, \& Pérez-Rodríguez, 2018).

In this context, where the presumption is a preponderant activity, the quality of the contents constitutes one of the needs towards which the media-digital or not-must turn their gaze. Therefore, their activity is not limited to being the environment of exhibition of the contents generated, protected under the idea of freedom offered by the Internet and especially by social networks.

Terms such as 'post-truth,' 'disinformation,' and 'fake news' have become particularly relevant in recent years, together with a greater interest on the part of users in consuming entertainment and pseudo-content but with little or no informative value. This implies that the notion of quality is not only subordinated to the productive routines of the media, but also to the role of the user as a consumer and producer of content.

Defining 'information quality' is not an easy task, since the very epistemology of 'quality' has subjective connotations, or is at least dependent on cultural perceptions-with specific standards linked to norms and values (Leggatt, 1996; Michnik \& Lo, 2009; Rosengren, Tagerud, \& Carlsson, 1996). In fact, it is almost impossible to reach a consensus on the meaning of 'information quality' among journalists, academics, and audiences (Baskarada \& Koronios, 2014; Gómez-Mompart, Gutiérrez-Lozano, \& Palau-Sampio, 2013; Urban \& Schweiger, 2014; Wallisch, 1995), because while for the latter 'quality' may reflect the expositive clarity of the message, or be implicit in the brand of the medium it publishes, information quality for a journalist may be related to the time it has taken him to access suitable sources and verify information (Baskarada \& Koronios, 2014; Gómez-Mompart et al., 2013; Urban \& Schweiger, 2014; Wallisch, 1995). On the other hand, from an academic point of view, there have been several proposals on quality, being the main ones identified in Table 1.

In terms of the quality of digital information, it has been shown that this one is crucial in areas such as media reputation (Madhikermi, Kubler, Robert, Buda, \& Framling, 2016), innovation and return on investment (Lee, Chen, \& Hartmann, 2016), audience confidence (Berezan, Yoo, \& Christodoulidou, 2016), user satisfaction (Ghasemaghaei \& Hassanein, 2016; Leite, Gonçalves, Teixeira, \& Rocha, 2016), and receiver market loyalty (Wang, Li, Li, \& Wang, 2014).

\section{Taxonomies and Models for Evaluating Information Quality in Digital Media}

Most of the models and taxonomies of analysis of informative quality has been carried out with analogies of evaluation structures of printed media. Urban and Schweiger (2014) structure six dimensions of information quality: 1) diversity (of points of view and sources); 2) relevance (in terms of the usefulness of information for decision-making); 3) accuracy (of information in relation to events); 4) comprehensibility (in terms of what should be understandable to audiences); 5) impartiality (to ensure neutral and balanced information coverage); and 6) ethics (to respect people's fundamental rights and maintain moral attitudes).

Costera-Meijer (2012) presents a second method of evaluating and valuing journalism from user experiences through common patterns such as participation (interactive component), representation (semantic component), and presentation (aesthetic component). A third model, authored by van der Wurff and Schönbach (2011), catalogues and assesses the elements and the informative quality in terms of codes of conduct and transparency from a scale of 5 points as follows: carefully check the facts (4.7); separate editorial content from advertising (4.6); complete the identification of sources (4.5); avoid the use of pseudonyms by journalists (4.4); do not manipulate images or statements (4.4), plurality of opinions (4.4); understandability of information (4.2); transparency, (4.1); separate facts from opinions (4.1); objectivity (3.9); protection of privacy (3.8); classification of news by importance (3.7); separate entertainment information (3.5); only publish information with informative values (3.0); publish quickly (2.9); respond to requests from audiences (2.4); and entertain the audience (2.2).

Integrating the four previous models, RomeroRodríguez et al. (2016) carry out an integrated model of assessment and evaluation of information quality, in which 75 indicators are divided into three macrodimensions: pre-communicative factors of the media as a business; socio-labor and educational situation of the journalists; and analysis of the content. In addition to being validated by a three-way Delphi, this model has had an application test in Spanish and Venezuelan media (Romero-Rodríguez \& Aguaded, 2018), as a pilot test to verify its usability in European and Latin American contexts.

\section{Materials and Methods}

The research is of mixed nature and is carried out in the Latin American context. An analysis of the content of the most important digital native media of 20 countries in the region was carried out based on a taxonomy of dimensions and qualitative indicators expressed in the third macro-dimension of Romero-Rodríguez et al. (2016), which focuses on the evaluation of the informative contents of the media.

The objective is to determine the quality of content published by digital native media in Latin America and to make a comparison between the media under study. For the purposes of the scope of this research, a codebook was elaborated with the different variables 
Table 1. 'Information quality' from the academic perspective.

\begin{tabular}{ll}
\hline Author(s) & Contribution \\
\hline Halloran, Elliot, and & The formula of having informative quality is to measure the integrity and objectivity of a \\
Murdock (1970); & journalistic narration, for which a contrast of the information published directly with the \\
Lang \& Lang (1953); & eyewitnesses of an event has to be made.
\end{tabular}

Meyer (1987)

Rosengren (1979)

The most appropriate method to verify the existence of informative quality is to contrast journalistic discourse with statistical data or independent documentation.

McQuail (1992) He defines the quality of information from the perspective of the public interest, which is why the criteria for its evaluation are derived from Western values such as freedom, equality, and order.

Schultz $(1996,2000) \quad$ The quality of information depends on three existential elements: the availability of adequate resources; a political and legal order that protects and guarantees the freedom of the exercise of the media; and the adherence of the journalist to professional standards. Aspects such as the diversity of media, ideologies represented, and objectivity are also essential. The quality of information is not only subjected to the internal conditions of the medium, but also to the context in which it is inserted.

Picard (2004) Information quality occurs when the number of information produced by the organization itself is more significant than that generated by external agents and when information and education deprive people of entertainment content, bearing in mind that this own content must follow a method of obtaining information, such as having a variety and contrast of information sources, as well as technical efficiency of the organization to allow products to be organized and understandable.

Bates (2005);

Hjørland (2007)

Bird (2010);

Costera-Meijer (2012); Madianou (2010);

Martin (2008)

Mai (2013)
Objectivity does not necessarily define information quality since subjective perceptions and views of a fact are also information in themselves.

The excellence in the exercise of journalism is faced with changes in habits of informative consumption, a trend that prioritizes entertainment content over any evidence of quality.

Consumers are no longer looking for any information; they are looking for complete information about their interests on the Internet. In this sense, quality is present in informative completeness. of the study, which were proposed taking as reference the previous research carried out by Romero-Rodríguez and Aguaded (2016), duly validated in Romero-Rodríguez et al. (2016) and Rivera-Rogel, Zuluaga-Arias, Ramírez, Romero-Rodríguez, and Aguaded (2017), which evaluates the quality of media content around 10 variables, each rated with a relative score based on the importance attributed to the quality of the content.

The variables selected for the development of this study are those that exclusively evaluate the quality of the information from the final product (see RomeroRodríguez et al., 2016) and are applied to the digital native media of Latin America. These variables are detailed in Table 2.

Assigning a score to each variable was not an easy task, since there are no defined standards to value the journalistic contents of the media, and since quality is something intangible, its value is linked to universally accepted values (Puente, 2004). For this reason, for the assignment of the highest scores, the basic principles of journalism have been considered, which emphasize the commitment to truth, the contrast of sources, and the disassociation of political and economic interests as fundamental journalistic practices. These were valued on 10 points and the others between $5,4,3$, and 2 respectively, based on expert opinion.

Traditional indicators such as precision and objectivity are implicitly valued in the variables considered in this study, such as: obtaining information, sources, content, and use of statistics, all of which make it possible to contrast and deepen the published information, it being impossible in absolute terms - as is logical - to evaluate objectivity based on any taxonomy or model.

For the development of the content analysis of the media understudy, a nonprobabilistic constructed week sample was carried out (Krippendorff, 1997; Stempel, 1989) for three months: from August to October 2019 (Table 3). The constructed week model is frequently used in qualitative studies and contemplates a random and stratified selection of samples for study trying to 
Table 2. Dimensions and assessment of the informational quality of digital media content.

\begin{tabular}{ll}
\hline Dimension & Scope \\
\hline Comments and monitoring & $\begin{array}{l}\text { Evaluates the existence of comment sections on the media page and whether the } \\
\text { administrator is involved. }\end{array}$ \\
Obtaining information & $\begin{array}{l}\text { Evaluates the amount of information that comes from the media's production } \\
\text { routines, and that is taken from news agencies and other media. }\end{array}$ \\
Sources & $\begin{array}{l}\text { The number of sources, informative contrast, direct sources, and identification } \\
\text { of sources. }\end{array}$ \\
Contents & $\begin{array}{l}\text { Focused on the format of presentation of the contents of the media, specifically } \\
\text { to the use of journalistic genres and the types of contents they develop (political, } \\
\text { social, community). } \\
\text { It allows knowing if the media focuses on the city, country, or region to which they } \\
\text { belong and if it takes other regions with the same importance. }\end{array}$ \\
Opinion & $\begin{array}{l}\text { Ideological balance in the opinion section observing the diversity of columnists } \\
\text { and collaborators who write for the media. } \\
\text { Concerning the content of the note: short, informative, and guiding. }\end{array}$ \\
Presentation quality & $\begin{array}{l}\text { Presence of the five W's of journalism (what, who, when, where, why-and how) } \\
\text { and correction of the language. } \\
\text { Correctly uses statistical indicators and infographics. } \\
\text { Use of stats }\end{array}$ \\
\hline
\end{tabular}

represent all the days of the week in an equitable way, and in this particular case, considering the daily and monthly variations in the media publications, this sampling method adjusts to the cyclical character of the information together with the variability of the informative agendas of the media. Thus, media publications were chosen for the Monday of the first week of the first month, Tuesday of the second week, Wednesday of the third week, Thursday of the fourth week, and so on until Sunday and completing one week, after which the week is repeated under the same dynamic until completing the three months of the study.

Table 3. Sampling schedule.

\begin{tabular}{lcl}
\hline Month & Week & Day \\
\hline August & 1 & Monday 5 \\
& 2 & Tuesday 13 \\
& 3 & Wednesday 21 \\
& 4 & Thursday 29 \\
September & 1 & Friday 6 \\
& 2 & Saturday 14 \\
& 3 & Sunday 22 \\
& 4 & Monday 23 \\
October & 1 & Tuesday 1 \\
& 2 & Wednesday 9 \\
& 3 & Thursday 17 \\
& 4 & Friday 25 \\
\hline
\end{tabular}

As it is a research on digital native media, it is necessary to point out that the review was carried out around the contents generated during the 24 hours of the selected days, which allows for the evaluation of a considerable number of informative units. The purpose is to collect the contents published in this diversity of fluctuations, and not only at a certain time.

The media to be studied were identified through the media directory Sembramedia, according to which there are 669 digital native media in Latin America: Argentina (64), Bolivia (11), Brazil (76), Chile (63), Colombia (82), Costa Rica (20), Cuba (15), Ecuador (48), El Salvador (13), Guatemala (19), Honduras (9), Mexico (75), Nicaragua (14), Panama (7), Paraguay (11), Peru (41), Puerto Rico (9), Dominican Republic (26), Uruguay (25), and Venezuela (52). To these are added 25 others classified as regional.

In this context, 20 digital native media were selected (Table 4), one for each country, having a website being the primary requirement, since Sembramedia considers fan pages on Facebook, Twitter profiles, YouTube, Vimeo, and Vine channels within the formats of digital native media. Another criterion for media selection was their position in the Alexa.com ranking.

\section{Results}

The analysis evaluated the quality of digital native media content in Latin America, considering the ten variables described in Table 3. It is necessary to emphasize that quality is an intangible property, but not impossi- 
Table 4. Analysis units.

\begin{tabular}{lllr}
\hline Country & Media & Website & Position in Alexa Country Ranking \\
\hline Argentina & Chequeado & www.chequeado.com & 614 \\
Bolivia & Periódico Digital PIEB & www.pieb.com.bo & 1180 \\
Brazil & La Lupa & https://piaui.folha.uol.com.br/lupa & 35 \\
Chile & The Times Chile & https://thetimes.cl & 55 \\
Colombia & Pulzo & www.pulzo.com & 3 \\
Costa Rica & CR Hoy & www.crhoy.com & 3 \\
Cuba & 14 y medio & www.14ymedio.com & 7907 \\
Ecuador & Primicias & www.primicias.ec & 105 \\
El Salvador & La Página & www.lapagina.com.sv & 7 \\
Guatemala & Soy 502 & www.soy502.com & 4 \\
Honduras & Tiempo hn & https://tiempo.hn & 7 \\
Mexico & Aristegui Noticias & https://aristeguinoticias.com & 102 \\
Nicaragua & Confidencial & www.confidencial.com.ni & 59 \\
Panama & Lucir Bien & www.lucirbien.com & 343 \\
Paraguay & Smash & https://medium.com/smashasu & 76 \\
Peru & La Mula & www.lamula.pe & 861 \\
Puerto Rico & Noticel & www.noticel.com & 56 \\
Dominican Republic & Acento & http://acento.com.do & 63 \\
Uruguay & Dnegocios.uy & www.dnegocios.uy & 1.299 .663 \\
Venezuela & El Cooperante & www.elcooperante.com & 132
\end{tabular}

ble to value, since to each variable to measure the quality of the contents was assigned a score based on expert judgment.

Through the variable 'comments,' it became evident that all the media include not only comment sections, but other forms of interaction such as forums and voting/valuation of the news, but do not develop an interaction with the user, a transcendental issue if we consider that comments are the way to enable communication between the media and users, something that has been since before the arrival of the Internet, through letters to the director, telephone calls and, in more modern times, messages through cell phones (Pinto, Barredo, Arcila, \& Suing, 2018), but that in the digital context can be a tool that allows the media to visualize how to monetize content.

In spite of the fact that the evaluation of the commentary sections of the digital native media constitutes a key exercise-considering that through them the media promotes the development of a critical perspective of the users in front of the contents that the media offers them, while motivating their credibility - they cannot be an indicator of the quality of the media, since it is not demonstrated that the users have the competences to develop quality contents or to influence in the construction of the informative unit.

Concerning the 'obtaining of information,' the digital native media bet for the most part on the development of journalistic routines that allow them to obtain their information, with which they can compete with other media. It is no less accurate that news agencies are present in the media, especially in the international news sections, and to a lesser extent other media since it is almost impossible for these digital ventures to have their correspondents outside their borders. This does not imply the existence of quality in the process of obtaining information, because they do not develop their own research routine that allows the medium to contrast with primary sources, and at the same time give them the appropriate space according to their relevance, contextualize the facts, and avoid informational distortion.

On the 'informative sources,' a variety of them is observed in a general way, especially in means like Chequeado (Colombia) and La Lupa (Brazil), dedicated to the verification of information. Aristegui Noticias (Mexico) is not far from it either. The opposite case is observed in Pulzo (Colombia), PIEB (Bolivia), and Dnegocios (Uruguay), where there is a limited number of direct sources, and instead, they refer to publications of informative agencies or other means of the country. Others, such as The Times Chile (Chile), El Cooperante (Venezuela), Dnegocios (Uruguay), and 14 y medio (Cuba), use one or no direct source, their style being conversational rather than informative.

The evaluation of information sources is essential to measure the quality of a journalistic work. This study took into consideration the number, characteristics, origin, and initiative of sources. In this sense, the existence of a diversity of types of sources is evident. The media analyzed use documents and statements from which they make analyses and interpretations. They also use other media as informative references, although there is a prevalence of 'unisourcism,' as well as the use of two and three sources. No less common is the use of official pages and social networks, and the same form of information from international agencies. In addition, it 
should be noted that direct interviews are not appreciated. These results show that there is no adequate management of sources.

Regarding 'media content,' the most exploited genres are news, over reporting, chronicle, and other genres. This corresponds to the logic of the mass media in general since news is the genre that occupies the most significant space in printed editions and radio and television news, but which is also better used given the immediacy and volatility of digital information. The reports are developed according to the need for topics that require a broad contextualization and a detailed treatment, and not immediate as news require. In addition, there is the use of headlines as a means of drawing the reader in. There was no evidence of the use of headlines unlinked from the content to attract readers (click-baiting), except in sponsored content where this practice does occur, as observed in La Página (El Salvador) and El Cooperante (Venezuela).

In this framework, from the point of view of quality, it is necessary to differentiate the contents that are presented under the journalism label, developed without control and created specifically to attract clicks, helping to feed the infoxication sphere where the user does not yet establish the skills that allow him to discriminate quality contents on the Web.

On the other hand, the exercise of investigative journalism by media such as CR Hoy (Costa Rica), Aristegui Noticias (Mexico), and Acento (Dominican Republic), which present more extensive investigations carried out in-depth with a diversity of sources and information, is noteworthy. In addition to this, it is emphasized that Latin American media bet on a diverse content, not centered on one country, but covering the region they are part of and the world, maintaining the global logic of the digital media. Despite this, Tiempo $h n$ (Honduras), 14 y medio (Cuba), Periódico Digital PIEB (Bolivia), Chequeado (Argentina), Primicias (Ecuador), and El Cooperante (Venezuela) are media that mostly develop national information.

The presence of opinion within the media is an aspect that is worth highlighting, since in certain contexts it can contribute to orienting social discussion on various topics, but it is no less true that on the other hand, it can become an aggregate of personal positions, which the media rarely contrasts with opinions of different kinds, thus encouraging the reader to opt for access to different points of view, especially if it is open access. The study noted that only La Lupa (Brazil) does not offer free access to this section and requires a paid subscription. In the other cases, most media include opinion sections dedicated especially to the analysis of various topics including, but not limited to, politics.

Except for Lucir Bien (Panama), Smash (Paraguay), La Mula (Peru), and Dnegocios (Uruguay), all other media include opinion sections. In these sections, 14 y medio (Cuba), Confidencial (Nicaragua), and El Cooperante (Venezuela) develop an opinion section openly contrary to the regime of their countries, which is also reflected in the informative treatment of the news. It is important to note that Lucir Bien (Panamá), Noticel (Puerto Rico), Dnegocios (Uruguay), and Smash (Paraguay) have focused on issues of social interest, detached from politics and rooted in culture, social issues, technology, business, and entertainment, covering issues that are not present in the media that focus mostly on political immediacy.

On the variant 'quality,' it was generally evident that the digital native media develop journalistic practices that aim towards innovation, both in content and in the way they are presented; however, there are notable differences between them. Media such as Chequeado (Argentina), CR Hoy (Costa Rica), La Lupa (Brazil), and Aristegui Noticias (Mexico) have bet towards the use not only of photography as a means of illustration of their contents but also of audiovisuals and infographics, which has allowed some of them like La Lupa (Brazil) to restrict access to all their materials, a subscription being necessary, which can be a useful source of financing considering the interest of the themes and narrative resources. This is especially important if one believes that new media must, at the same time, seek alternative sources to advertising to sustain themselves.

Perhaps, for this reason, the media mentioned above occupy relevant places in their countries according to the ranking of Alexa.com. All of them are among the top 50, with the exception of Aristegui Noticias (Mexico), which is not even in the top 100. In the case of Colombia, Pulzo, and Costa Rica, CR Hoy, both media are third in the ranking, only after Google and YouTube. Uruguay is perhaps the country where digital native media has not yet finished positioning itself among users by the number of visits.

Finally, 'photographs and other multimedia resources' are an essential part of digital publications, as is the 'use of statistical resources.' The latter was only observed in a quarter of the media, while photographs are present in all media. It is worth noting the use of other resources such as infographics, audios, videos, and downloadable documents, which complement the information. Media such as Soy 502 (Guatemala), La Página (El Salvador), and Aristegui Noticias (Mexico) include complete sections of multimedia material and even live broadcasts. Others use photographs only to illustrate information, although they do not always belong to the information, as in the case of El Cooperante (Venezuela) and Dnegocios (Uruguay; Table 5).

\section{Conclusion and Discussion}

The constant management of information is a practice that must be conditioned by the application of quality parameters. However, this does not always lead to economic returns for the media as a business. This reality leads to the construction of different models of information quality that respond to specific environments. The parameters proposed here are aimed at analyzing the 
Table 5. Assessment of digital native media content.

\begin{tabular}{|c|c|c|c|c|c|c|c|c|c|c|c|}
\hline Media & 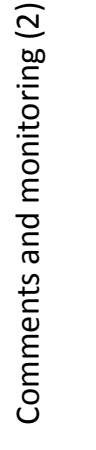 & 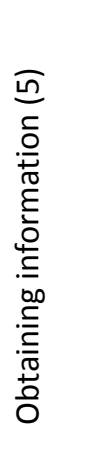 & 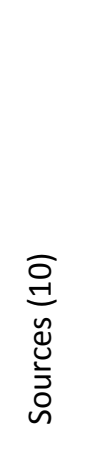 & 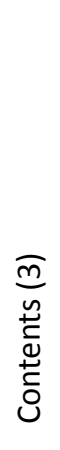 & 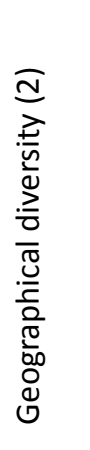 & 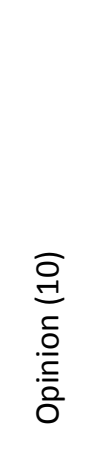 & 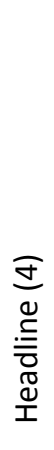 & 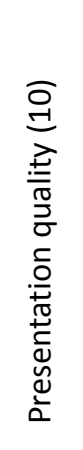 & 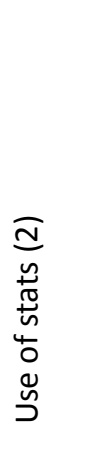 & $\begin{array}{l}\widetilde{N} \\
\text { n } \\
\frac{c}{0} \\
\frac{0}{0} \\
\frac{0}{00} \\
0 \\
\frac{0}{0} \\
\frac{c}{0}\end{array}$ & $\begin{array}{l}\bar{\pi} \\
\stackrel{0}{0} \\
\end{array}$ \\
\hline Chequeado & 2 & 5 & 10 & 3 & 2 & 10 & 4 & 10 & 2 & 2 & 50 \\
\hline Periódico Digital PIEB & 1 & 2.5 & 6 & 3 & 1 & 5 & 4 & 8 & 2 & 0.5 & 33 \\
\hline La Lupa & 1 & 5 & 10 & 3 & 2 & & 4 & 10 & 2 & 2 & 39 \\
\hline The Times Chile & 1 & 5 & 5 & 3 & 2 & 10 & 4 & 8 & 2 & 2 & 42 \\
\hline Pulzo & 1 & 2.5 & 5 & 3 & 2 & 10 & 4 & 6 & 0 & 2 & 35.5 \\
\hline CR Hoy & 1 & 5 & 10 & 3 & 2 & 10 & 4 & 10 & 1 & 2 & 48 \\
\hline 14 y medio & 1 & 5 & 10 & 3 & 2 & 5 & 4 & 10 & 0 & 2 & 42 \\
\hline Primicias & 1 & 5 & 8 & 3 & 2 & 10 & 4 & 10 & 2 & 2 & 47 \\
\hline La Página & 1 & 5 & 8 & 3 & 2 & 10 & 4 & 6 & 0 & 2 & 41 \\
\hline Soy 502 & 1 & 5 & 8 & 3 & 2 & 10 & 4 & 10 & 0 & 2 & 45 \\
\hline Tiempo hn & 1 & 5 & 10 & 3 & 2 & 10 & 4 & 10 & 0 & 2 & 47 \\
\hline Aristegui Noticias & 1 & 5 & 10 & 3 & 2 & 10 & 4 & 10 & 2 & 2 & 49 \\
\hline Confidencial & 1 & 5 & 8 & 3 & 2 & 5 & 4 & 8 & 0 & 2 & 38 \\
\hline Lucir Bien & 1 & 5 & 9 & 3 & 2 & 0 & 4 & 10 & 0 & 2 & 36 \\
\hline Smash & 1 & 5 & 5 & 3 & 2 & 0 & 4 & 9 & 0 & 2 & 31 \\
\hline La Mula & 1 & 5 & 10 & 3 & 2 & 0 & 4 & 10 & 0 & 2 & 37 \\
\hline Noticel & 1 & 5 & 10 & 3 & 2 & 5 & 4 & 8 & 0 & 2 & 40 \\
\hline Acento & 1 & 3 & 10 & 3 & 2 & 5 & 4 & 8 & 0 & 2 & 38 \\
\hline Dnegocios & 1 & 3 & 3 & 3 & 2 & 0 & 4 & 10 & 0 & 1 & 27 \\
\hline El Cooperante & 1 & 3 & 4 & 3 & 2 & 0 & 4 & 5 & 0 & 1 & 23 \\
\hline Total & 1.05 & 4.45 & 7.95 & 3 & 1.95 & 6.05 & 4 & 8.8 & 0.65 & 1.83 & 39.73 \\
\hline
\end{tabular}

content of the medium as a final product, which evaluates ten dimensions: comments and monitoring, obtaining information, sources, content, geographical diversity, opinion, title, quality of presentation, use of stats, and photographs (Romero-Rodríguez et al., 2016).

It is essential to consider that any information practice requires quality guarantees, which seeks to make the media responsible for the quality of the information they publish, considering the dimensions analyzed in this study. The study shows that, although there is an interest in the quality of content in digital native media-evidenced in the variety of content, use of diverse sources, quality of presentation, resources used, and geographical diversity-this is not a constant in the totality of the media analyzed, added to the fact that the way of applying the different dimensions studied are not directly synonymous with quality; for example, a greater number of sources does not necessarily imply that the final product has quality, as explained above.

The dimensions that reach the highest score with $100 \%$ are 'content' and 'headline.' This is mainly because digital native media tend to renew their content con- stantly without considering the innovation of their professional procedures and technological resources. On the other hand, it has to be considered that changes in users' consumption habits have motivated them not only to generate their own content, but also to look for topics that respond to their interests, which are not always informative, but tend more towards entertainment and fiction. The latter is what makes the consumption of falsified information possible and the promotion of the misinformative phenomenon that is spread mainly as entertainment.

The least valued dimensions are precisely those related to the characteristics of digital journalism: 'comments and monitoring' (52.5\%) and 'use of statistical indicators' (32.5\%). That is to say that the media do not give importance to the participation of users, which is a critical point because participation could serve, at the same time, to contrast the effectiveness of the media and journalists and to select the subject matter that makes up the thematic agenda of the media. On the other hand, a pending issue for the media under study is the use of technical indicators (data journalism), that today is cru- 


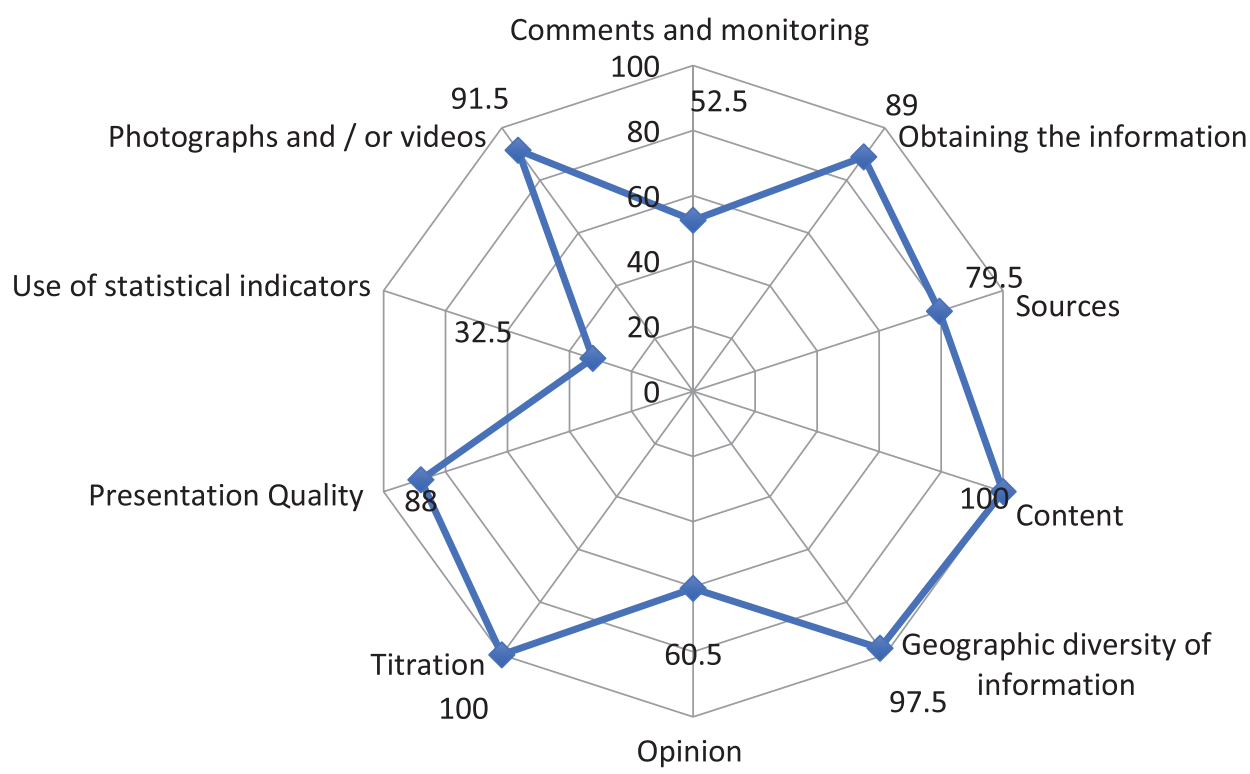

Figure 1. Average rating (in percent) of dimensions of digital native media in Latin America.

cial for enriching the information (see Figure 1). The results of these two dimensions make it possible to contrast what was stated in the previous paragraph, even though the media do not give way to the new modalities and languages that digital native media demand.

In spite of the fact that in many countries of the region there are still vast inequalities of access to information due to digital gaps of economic, age, and geographical reasons (Lotero-Echeverri et al., 2018), the more than 669 digital native media registered in Latin America are a sample of the expansion of new media in Latin America. These results also support the study by Salaverría et al. (2019), in the sense that digital native media in the last two decades, in many occasions, managed to reach high degrees of consolidation.
From the analysis, it emerges that the means that achieve the maximum score is Chequeado, from Argentina (50 points), and the one who scored the least is El Cooperante (Venezuela), with 23 points. However, all the media under study should improve certain aspects, such as the use of multimedia as a way to capture the interest of users in different platforms (see Figure 2).

The quality of the information found in Latin America's digital native media cannot be evaluated only through the final product (content), since this analysis can be incomplete or subjective, added to the fact that more and more media are pointing to the development of content based on investigative journalism. Thus, a complete evaluation of the quality of the information must take into account all the aspects involved in the cre-

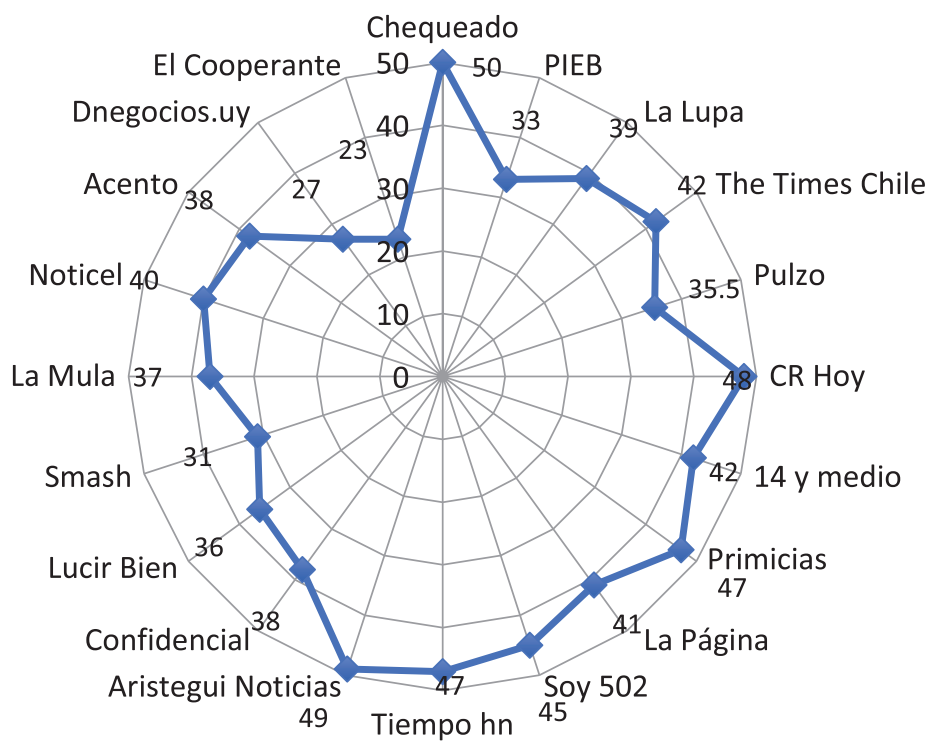

Figure 2. Global scoring of Latin America's digital native media. 
ation of the information, starting from the business nature of the medium and its pre-communicative factors (economic, political, and social), to the socio-labor situation of the journalists.

The path to quality media content should consider different criteria for its shaping. In this sense, the present study could constitute a reference and background framework applicable from its own experience and context.

The authors of this research recognize that in the process of evaluating the quality of digital native media, the focus on content is not sufficient to determine the quality of the media as a whole, due to the factors mentioned above: changes in consumer habits; increased misinformation; entertainment; among others. Therefore, the present study constitutes a first approach to the evaluation of the quality of the contents of the digital native media in Latin America, and will serve as a support for future studies that allow for the visualization of other aspects of the digital media in Latin America: business factors; economic issues of the news company; social and labor situation of its journalists; as well as issues related to the distribution of information. In the same way, a future challenge will be the study of the influences of various actors, such as political, corporative, economic, and social ones in the generation of content in digital native media.

\section{Acknowledgments}

This work is conducted within the framework of 'Alfamed' (Euro-American Network of Researchers), with the support of the R+D Project "Youtubers and Instagrammers: Media Competence in Emerging Prosumers" (RTI2018093303-B-I00), financed by the State Research Agency of the Spanish Ministry of Science, Innovation and Universities and the European Regional Development Fund (ERDF).

\section{Conflict of Interests}

The authors declare no conflict of interests.

\section{References}

Albright, J. (2017). Welcome to the era of fake news. Media and Communication, 5(2), 87-89. https://doi.org/ 10.17645/mac.v5i2.977

Baskarada, S., \& Koronios, A. (2014). A critical success factor framework for information quality management. Information Systems Management, 31(4), 276-295. https://doi.org/10.1080/10580530.2014.958023

Bates, M. J. (2005). An introduction to metatheories, theories, and models. In K. E. Fisher, S. Erdelez, \& L. McKechnie (Eds.), Theories of information behaviour (pp. 1-24). Medford, NJ: Information Today.

Berezan, O., Yoo, M., \& Christodoulidou, N. (2016). The impact of communication channels on communication style and information quality for hotel loyalty programs. Journal of Hospitality and Tourism Technology, 7(1), 100-116. https://doi.org/10.1108/JHTT08-2015-0031

Bird, S. E. (2010). News practices in everyday life: Beyond audience response. In S. Allan (Ed.), The Routledge companion to news and journalism (pp. 417-427). London: Routledge.

Costera-Meijer, I. (2012). Valuable journalism: A search for quality from the vantage point of the user. Journalism, 14(6), 754-760. http://dx.doi.org/10.1177/ 1464884912455899

García-Serrano, J., Romero-Rodríguez, L. M., \& Hernando Gómez, A. (2019). Análisis del "clickbaiting" en los titulares de la prensa española contemporánea/Estudio de caso: Diario "El País" en Facebook [Analysis of clickbaiting in contemporary Spanish press headlines/A case study: El País on Facebook]. Estudios sobre el Mensaje Periodístico, 25(1), 197-212. https://doi.org/10.5209/ESMP.63724

Ghasemaghaei, M., \& Hassanein, K. (2016). A macro model of online information quality perceptions: $A$ review and synthesis of the literature. Computers in Human Behavior, 55(Part B), 972-991. https://doi. org/10.1016/j.chb.2015.09.027

Gómez-Mompart, J. L., Gutiérrez-Lozano, J. F., \& PalauSampio, D. (2013). La calidad periodística: Teorías, investigaciones y sugerencias profesionales [The journalistic quality: Theories, research and professional suggestions]. Barcelona: UPF. http://dx.doi.org/ 10.7203/puv-alg26-9164-8

Halloran, J., Elliot, P., \& Murdock, G. (1970). Demonstrations and communication: A case of study. Harmondsworth: Penguin Books.

Hjørland, B. (2007). Information: Objective or subjective/situational? Journal of the American Society for Information Science and Technology, 58(10), 1448-1456. https://doi.org/10.1002/asi.20620

Krippendorff, K. (1997). Metodología de análisis de contenido: Teoría y práctica [Content analysis methodology: Theory and practice]. Buenos Aires: Editorial Paidós.

Lang, K., \& Lang, G. (1953). The unique perspective of television and its effect: A pilot study. American Sociological Review, 18(1), 2-12.

Lazer, D., Baum, M., Benkler, Y., Berinsky, A., Greenhill, K., Menczer, F., . . Zittrain, J. (2018). The science of fake news. Science, 359(6380), 1094-1096. https:// doi.org/10.1126/science.aao2998

Lee, R. P., Chen, Q. M., \& Hartmann, N. N. (2016). Enhancing stock market return with new product preannouncements: The role of information quality and innovativeness. Journal of Product Innovation Management, 33(4), 455-471. https://doi.org/10.1111/ jpim. 12284

Leggatt, T. (1996). Identifying the indefinable: An essay on approaches to assessing quality in the UK. In S. Ishikawa (Ed.), Quality assessment of television (pp. 411-424). Bedfordshire: John Libbey. 
Leite, P., Gonçalves, J., Teixeira, P., \& Rocha, A. (2016). A model for the evaluation of data quality in health unit websites. Health Informatics Journal, 22(3), 479-495. https://doi.org/10.1177\%2F1460458214567003

Lotero-Echeverri, G., Romero-Rodríguez, L. M., \& PérezRodríguez, M. A. (2018). 'Fact-checking' vs. 'fake news': Periodismo de confirmación como recurso de la competencia mediática contra la desinformación ['Fact-checking' vs. 'fake news': Confirmation journalism as a tool of media literacy against misinformation]. Index Comunicación, 8(2), 295-316.

Madhikermi, M., Kubler, S., Robert, J., Buda, A., \& Framling, K. (2016). Data quality assessment of maintenance reporting procedures. Expert Systems with Applications, 63(30), 145-164. https://doi.org/ 10.1016/j.eswa.2016.06.043

Madianou, M. (2010). Living with news: Ethnographies of news consumption. In S. Allan (Ed.), The Routledge companion to news and journalism (pp. 428-438). London: Routledge.

Mai, J.-E. (2013). The quality and qualities of information. Journal of the American Society for Information Science and Technology, 64(4), 675-688. https://doi. org/10.1002/asi.22783

Martin, V. B. (2008). Attending the news: A grounded theory about a daily regimen. Journalism, 9(1), 76-94. http://dx.doi.org/10.1177/1464884907084341

McQuail, D. (1992). Media performance: Mass communication and the public interest. London: Sage.

Meyer, P. (1987). Ethical journalism. New York, NY: Longman.

Michnik, J., \& Lo, M. C. (2009). The assessment of the information quality with the aid of multiple criteria analysis. European Journal of Operational Research, 195(3), 850-856. https://doi.org/10.1016/ j.ejor.2007.11.017

Molyneux, L., \& Coddington, M. (2019). Aggregation, clickbait and their effect on perceptions of journalistic credibility and quality. Journalism Practice. Advance online publication. https://doi.org/10.1080/ 17512786.2019.1628658

Novak, A. (2018). Designing a renaissance for digital news media. Media and Communication, 6(4), 115-118. https://doi.org/10.17645/mac.v6i4.1769

Picard, R. G. (2004). Commercialism and newspaper quality. Newspaper Research Journal, 25(1), 54-66.

Pinto, K., Barredo, D., Arcila, C., \& Suing, A. (2018). La interactividad como un factor clave para la fidelización de las audiencias: Una aproximación al contexto colombiano [Interactivity as a key factor for audience loyalty: An approach to the Colombian context]. In C. Arcila, D. Barredo, C. Castro, A. Hernández, \& D. de la Garza (Eds.), Comunicación digital, redes y procesos en América Latina [Digital communication, networks and processes in Latin America] (pp. 39-48). Salamanca: Comunicación Social Ediciones y Publicaciones.

Puente, S. (2004). Instrumento para evaluar la calidad pe- riodística: EI VAP compara a la prensa y televisión de Hispanoamérica [Instrument to evaluate journalistic quality: VAP compares Latin American press and television]. Cuadernos.info, 2004(16), 101-113.

Rivera-Rogel, D., Zuluaga-Arias, L. I., Ramírez, N. M. M., Romero-Rodríguez, L. M., \& Aguaded, I. (2017). Media competencies for the citizenship training of teachers from Andean America: Colombia and Ecuador. Paideia, 27(66), 80-89. https://doi.org/ 10.1590/1982-43272766201710

Romero-Rodríguez, L. M., \& Aguaded, I. (2016). Consumption of information and digital competencies of journalism students from Colombia, Peru and Venezuela. Convergencia Revista de Ciencias Sociales, 2016(70), 1-20.

Romero-Rodríguez, L. M., \& Aguaded, I. (2018). Toward a taxonomy of newspaper information quality: An experimental model and test applied to Venezuela dimensions found in information quality. Journalism, 18(10), 1327-1345. https://doi.org/10.1177\% 2F1464884916663596

Romero-Rodríguez, L. M., De-Casas-Moreno, P., \& TorresToukoumidis, A. (2016). Dimensiones e indicadores de la calidad informativa en los medios digitales [Dimensions and indicators of the information quality in digital media]. Comunicar, 24(49), 91-100. https:// doi.org/10.3916/C49-2016-09

Rosengren, K. E. (1979). Bias in news: Methods and concepts. Studies of Broadcasting, 15(1), 31-45.

Rosengren, K. E., Tagerud, Y., \& Carlsson, M. (1996). Quality in programing: Views from North. In S. Ishikawa (Ed.), Quality assessment of television (pp. 21-80). Bedfordshire: John Libbey.

Salaverría, R. (2005). An immature medium: Strength and weaknesses of online newspapers on September 11. Gazette, 67(1), 69-86. http://dx.doi.org/ 10.1177/0016549205049179

Salaverría, R., Rivera-Rogel, D., \& González-Córdova, M. (2019). Taxonomía del periodismo digital en Iberoamérica: Evolución en las dos décadas digitales [Taxonomy of digital journalism in Latin America: Evolution in the two digital decades]. In L. M. RomeroRodríguez \& D. Rivera-Rogel (Eds.), La comunicación en el escenario digital: Actualidad, retos y prospectivas [Communication in the digital scenario: Present, challenges and future perspectives] (pp. 263-285). Lima: Pearson.

Salaverría, R., Sábada, C., Breiner, J. G., \& Warner, J. C. (2018). A brave new digital journalism in Latin America. In M. Túñez-López, V. A. Martínez-Fernández, X. López-García, X. Rúas-Araújo, \& F. Campos-Freire (Eds.), Communication: Innovation \& quality (pp. 229-247). Bern: Springer.

Samuel-Arzan, T., \& Hayat, T. (2019). Online news recommendations credibility: The tie is mightier than the source. Comunicar, 27(60), 71-80. https://doi.org/ 10.3916/C60-2019-07

Schultz, W. (1996). Qualität von Fernsehprogrammen 
[Quality of television programmes]. In W. Hömberg \& H. Pürer (Eds.), Medien-Transformation: Zehn Jahre dualer Rundfunk in Deutschland [Media transformation: Ten years of dual broadcasting in Germany] (pp. 45-59). Konstanz: UVK Medien.

Schultz, W. (2000). Preconditions of journalistic quality in an open society. In Proceedings of International Conference News Media and Politics: Independent journalism (pp. 204-209). Budapest: Hungarian Europe Society.

Stempel, G. (1989). Content analysis. Upper Saddle River, NJ: Prentice-Hall.

Urban, J., \& Schweiger, W. (2014). News quality from the recipients' perspective. Journalism Studies, 15(6), 821-840. http://dx.doi.org/10.1080/1461670X. 2013.856670 van der Wurff, R., \& Schönbach, K. (2011). Between professionals and audience: Codes of conducts and transparency as quality instruments for off- and online journalism. Journalism Studies, 12(4), 407-422. http://dx.doi.org/10.1080/1461670X.2010.506055

Vosoughi, S., Roy, D., \& Aral, S. (2018). The spread of true and false news online. Science, 359(6380), 1146-1151. https://doi.org/10.1126/ science.aap9559

Wallisch, G. (1995). Journalistische Qualitaet: Definitionen (Modelle) Kritik [Journalistic quality: Definitions (models) review]. Konstanz: UVK.

Wang, Y. S., Li, H. T., Li, C. R., \& Wang, C. (2014). A model for assessing blog-based learning systems success. Online Information Review, 38(7), 969-990. https:// doi.org/10.1108/OIR-04-2014-0097

\section{About the Authors}
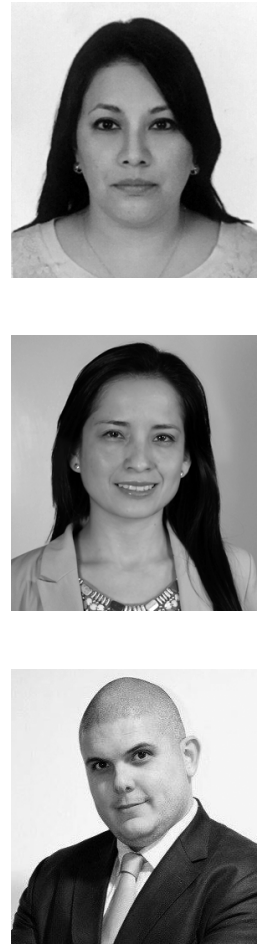

Claudia Rodríguez-Hidalgo is Lecturer of the Communication Degree at the Universidad Técnica Particular de Loja, Ecuador. She is a Member of the Euro-American Inter-University Network for Research on Media Competence for Citizenship (ALFAMED) and Associated Researcher at Education and Technologies and Communication, Power and Network citizenship research groups. She has a BSc in Social Communication and a MSc in Communication Research from the University of Navarra (Spain) and is a Doctoral Candidate of the Inter-University Doctoral Program in Communication of the universities of Cádiz, Huelva, Málaga, and Sevilla.

Diana Rivera-Rogel is a Senior Lecturer at the Universidad Técnica Particular de Loja (UTPL), Ecuador. She has a PhD in Communication and Journalism and a BSc in Social Communications. She is Director of the Socio-Humanistic Area of the UTPL, Coordinator of the Ecuadorian national chapter of the Euro-American Inter-University Network for Research on Media Competence for Citizenship (ALFAMED), and Coordinator of the Ecuadorian Communication Network (REDU). She has been an international Co-Editor for the scientific journal Comunicar (2013-2015).

Luis M. Romero-Rodríguez is a Senior Lecturer in the Department of Communication Sciences and Sociology at the Rey Juan Carlos University, Spain, and Visiting Professor at the ESAI Business School, Universidad Espíritu Santo, Ecuador. He is a Founding member of the Ibero-American Inter-University Research Network on Media Competencies for Citizenship (ALFAMED) and an Associate Researcher of the Ágora Group (PAI-HUM-648) at the University of Huelva. He is Associate Editor of the scientific journal Comunicar and Author of more than sixty publications on digital communication, journalism, and media competences. 